Oleksandr Naboka, Doctor of historical sciences, assistant professor, Taras Shevchenko National University of Lugansk, Starobilsk

\title{
DIPLOMATIC VISITS OF COMMODORE M. PERRY TO LIU CHUI ISLAND IN 1852 AND 1853 AND ITS INTERNATIONAL REPERCUSSIONS
}

The article highlights the diplomatic mission of the American Commodore M. Perry to Liu Chui Islands, during the large-scale military expedition of the US Navy Fleet to Japan in 1852 - 1853. The publication of official documents related to the mission of M. Perry, memoirs and travel notes of the members of that expedition were used as the information source.

The author believes that the main purpose of Perry's visit to Liu Chui Island was dictated by the desire to open the Island to American trade, and in the prospect, to bring the Island into subjection of the US protectorate.

Perry has used a range of methods to implement these tasks, from pure diplomacy to direct pressure using the armed assault.

As a result, the Commodore succeeded, and the Island, despite the protests of the local authorities in 1853, was opened to foreign trade. This action allowed US to become the second of the most powerful countries in East Asia after the United Kingdom.

The process of establishing the contacts between the leader of the expedition and the local authorities of the Island has been examined, as well as the conducted negotiations during the first (1852) and second (1853) Perry's visits to the capital of the archipelago - the city of Nappa, which resulted in opening this Island to Western trade.

For a long time the local governor has been dragging out the negotiations process, but he had to agree to the US' terms, after the US marines seized his palace up.

The United States had an opportunity to trade on Liu Chui Island, purchase the coal for their ships, so as they got freedom of movement across its territory.

However, after two decades, the United States abandoned the claims to the Islands. The reasons for this are to be investigated by the author in his following research works.

Keywords: M. Perry, Liu Chui Island, Japan, the United States.

УДК 327.56(73)+327.8

http://doi.org/10.17721/2521-1706.2017.03.103-113
Анатолій Худолій,

доктор політичних наук, професор, НаУОА, м. Острог

\section{АМЕРИКАНО-ТУРЕЦЬКІ ВІДНОСИНИ НА ПОЧАТКУ ХХІ СТОЛІТТЯ}

Анотація. В статті розглянуто американсько-туречькі відносини, починаючи $з$ 2000 до 2017 року. Проаналізовано основні тендениії розвитку американсько-туреиьких відносин в контексті двостороннього співробітництва за кадениії Дж. В. Буша, Б. Обами та Д. Трампа. Висвітлено діяльність Туреччини, спрямовану на стабілізацію ситуації в регіоні. Розглянуто безпекові аспекти зовнішньополітичної діяльності США та Турецької Республіки. В полі зору дослідника - політичні, військові та економічні аспекти співробітництва та відносини між Вашингтоном $i$ Анкарою упродовж зазначеного періоду. Виокремлено пріоритети Вашингтону у відносинах з Туреччиною з урахуванням власних прагматичних иілей та національних інтересів. Здійснено аналіз двосторонніх відносин в світлі війни в Афганістані. Описано чинники, щзо обмежують стратегічне партнерство двох країн. Деталізовано діяльність Туреччини як члена НАТО. Розглянуто конкретні кроки, здійснені США та Туреччиною задля регіональної безпеки. 
За підтримки Вашингтону посилюється роль Туреччини в перебігу подій в Афганістані. Описано активну участь Туреччини у вирішенні конфліктної ситуачії в Сирії. Військове співробітництво доповнюють економічні зв'язки та інтереси. Починаючи з 2000 року, Туреччина стала важливим ринком збуту американських товарів. Надаючи фінансову та військову допомогу, Вашингтон наполягає на зміцненні демократичних засад в Туреччині.

Ключові слова: США, Туреччина, американсько-турецькі відносини, Сирія, Афганістан.

Американське лідерство в світі привертає увагу широкого кола дослідників 3 урахуванням ролі Вашингтону у світовій та регіональні політиці. Пізнавальним у цьому плані виступає регіон Близького Сходу, де перетинаються інтереси значної кількості акторів, серед яких слід зауважити США та Турецьку Республіку. Незначна кількість досліджень присвячена американо-турецьким відносинам, роль яких, на нашу думку, недооцінена.

Зовнішній політиці США присвячено низку праць як вітчизняних, так i закордонних дослідників, серед яких I.I. Погорська [1], О.О. Головань [2], Л.Л. Кияниця [3], М. І. Ратніков [4], В.С. Московець [5], Чубрикова О. [6] та інші. I.I. Погорська зосередила увагу на міжнародно-політичній дії американської зовнішньої політики, не акцентуючи уваги на конкретних акторах, хоча, звісно, це значно б розширило межі іiі дослідження. О.О.Головань відстежив еволюцію зовнішньої політики США на початку XXI століття. Автор здійснив аналіз зовнішньополітичного курсу США за каденції Дж.В. Буша та Б. Обами, хоча варто було детальніше зупинитися на близькосхідній стратегії Вашингтону, враховуючи його цінність для Америки та світу загалом. Л.Л. Кияниця дослідив вплив “арабської весни” на співвідношення сил на Близькому Сході. На жаль, ії вплив на Туреччину розглянуто лише побіжно. В.С. Московець висвітлив курдське питання в американо-турецьких відносинах, хоча мало приділив увагу іншим аспектам співробітництва Вашингтону з Анкарою.

Побіжно турецької проблематики торкалися такі автори публікацій, як В. Каспрук [7], Д. Глухов [8] та інші. Певний внесок в розробку різноманітних аспектів американської проблематики зробили закордонні дослідники, серед яких $\epsilon$, як російські, так і західні науковці. Серед російських слід назвати здобутки I.А. Свистунової [9; 10], П.Є. Калугіна [11], О.А. Гур'єва [12], I.І. Стародубцева [13] тощо. Дисертація Д.В. Накісбаєва [14] цілковито присвячена американо-турецьким відносинам, проте відображає віддалені у часі події, оскільки датується 2008 роком.

Серед західних науковців політиці Туреччини присвятили свої праці Д. Санторо [15], Н. Голетт [16], М. Бесма [17;18], С. Масуд [19], С. Озель, С. Ілмаз [20], Т.Н. Фелікс [21] та інші. Тематика широка, вона охоплює як сучасні аспекти взаємовідносин, так і специфічні особливості обох країн.

Водночас слід зазначити, що проблема сучасного періоду американотурецьких відносин не стала предметом автономного вивчення.

Мета i завдання дослідження. Мета дослідження полягає у політикопраксеологічному дослідженні американо-турецьких відносин та зовнішньої політики Сполучених Штатів у контексті утвердження американського лідерства на Близькому Сході упродовж 2000-2017 pр.

Досягнення поставленої мети обумовлює вирішення таких завдань: 
-з'ясувати характер американо-турецьких відносин упродовж 2000-2017 років;

- виявити чинники, що впливали на розвиток двосторонніх відносин;

- виявити сфери найбільшого розвитку двосторонніх відносин упродовж згаданого періоду.

Американо-турецькі відносини навряд чи можна назвати простими, вони мають свої злети та падіння в залежності від тих або інших історичних подій та чинників, що на них впливали. Обидві країни переслідують власні цілі у зовнішньополітичній сфері, домінуючими в яких виступають національні інтереси. Початок третього тисячоліття виявився плідним для обох країн. Починаючи з 2001 року, Туреччина бере участь у воєнній операції коаліційних сил в Афганістані. А в серпні 2012 року було створену американо-турецьку міжвідомчу робочу групу по ситуації в Сирії. Військове співробітництво доповнюють економічні зв'язки та інтереси. Починаючи 32000 року, Туреччина стала важливим ринком збуту американських товарів. Щорічний експорт із США в Туреччину упродовж 20012011 pp. зріс з 3261 млн. до 16034 млн. доларів [11].

Аналізуючи двосторонні відносини, слід зауважити, що на міждержавному рівні діє низка угод i двосторонніх договорів, що торкаються політичних, військових, економічних, культурних та інших питань. Турецька Республіка розглядає Сполучені Штати Америки як головного стратегічного партнера в політичній, економічній, військовій та сфері безпеки [9]. Такий статус країнипартнера - не випадковий, оскільки Вашингтон не лише поставляе зброю до Анкари, але й підтримує іiі у фінансовій сфері, зокрема сприяє виділенню кредитів МВФ і Світового банку на програми стабілізації національної економіки. Як член НАТО Туреччина співпрацює 3 країнами-членами Альянсу, серед яких домінуючим партнером виступають США.

Американо-турецькі відносини упродовж каденції Дж. В. Буша були досить напруженими через непослідовну зовнішню політику Вашингтону. Деякі питання двостороннього військового співробітництва адміністрація Буша намагалася вирішити, використовуючи як важелі впливу міжнародні організації, зокрема МВФ. Америка була значною мірою зацікавлена у співпраці з Туреччиною, зокрема у питанні вторгнення в Ірак. За повідомленням газети Washington Post, в жовтні 2002 року відбулися перемовини між США та Турецькою Республікою щодо можливості американської допомоги в обмін на турецьке військове співробітництво. А вже через місяць адміністрація США почала домагатися від уряду Туреччини приєднання до коаліції проти Іраку. Зважаючи на значні економічні витрати, Вашингтон запропонував Туреччині (в грудні 2002 року відбулася зустріч між П. Вулфовіцем, чинним заступником Міністра оборони США i заступником Державного секретаря США М. Гроссманом, 3 одного боку, та прем'єр-міністром Туреччини Абдулом Гюль) своєрідну фінансову компенсацію в розмірі 4 млрд. доларів [17].

Згодом США запропонували Туреччині 6 млрд. дол. у вигляді грантів, конвертованих в 20 млрд. доларів у вигляді позик, в обмін на використання бази Інджирлік в Туреччині. Незважаючи на привабливість такої пропозиції, парламент Турецької Республіки відхилив іiі. Зацікавлені в співпраці, Сполучені Штати продовжують перемовини 3 Турецькою Республікою. Цього разу пропозиція передбачала 1 млрд. доларів в обмін на використання повітряного простору 
Туреччини ВПС США. В березні парламент Республіки дозволив США здійснювати перельоти над територією країни [18]. Незважаючи на фінансову підтримку Анкара не приховувала роздратування 3 приводу непослідовності політики Вашингтону в курдському питанні. Сполучені Штати відмовилися від обіцяних ними операцій проти курів на півночі Іраку [4].

Ситуація в двосторонніх відносинах між США та Туреччиною дещо поліпшилась після приходу до влади Б. Обами, який офіційно заявив про відродження стратегічних відносин між Вашингтоном та Анкарою [2]. Реакція бізнес спільноти Туреччини виявилась більш ніж позитивною. Турецька асоціація промисловців і підприємців акумулювавши зусилля, створила документ, своєрідну дорожню карту двосторонніх відносин під назвою "Rebuilding A Partnership: Turkish American Relations For A New Era. A Turkish Perspective”. Документ охоплює низку пропозицій, спрямованих на поліпшення двосторонніх відносин i поглиблення співробітництва. Пропозиції TÜSİAD, що торкалися Вашингтону, були такі:

1. Сприяти вступу Туреччини до $\mathrm{CC}$;

2. Сприяти остаточному вирішенню проблеми Кіпру;

3. Підтримати проект Набукко, забезпечити створення інфраструктури, необхідної для транспортування газу по газогону Набукко;

4. Гарантувати збереження особливого статусу м. Кіркук і не допустити його насильницького приєднання до Курдської автономії;

5. Допомогти в реалізації спільних енергетичних, торгівельних та інвестиційних проектів між Туреччиною і Курдським автономним районом Іраку;

6. Розробити та втілити програму підтримки спільних економічних ініціатив американських i турецьких компаній, як у Туреччині, так i на ринках сусідніх з Туреччиною країн.

Не менш важливою виявилась частина пропозицій, запропонованих Турецькому уряду. Серед них зокрема такі:

1. Демонструвати нейтральний підхід до проблем близькосхідного врегулювання;

2. Розвивати відносини з іракськими курдами;

3. Відкрити консульство в Ербілі;

4. Дотримуватися послідовної позиції спрямованої на припинення ядерної програми Ірану i, як наслідок, перетворення Ірану на ядерну державу;

5. Відкрити кордон з Вірменією, налагодити торгівельні зв'язки і взаємне інвестування;

6. Створити урядову структуру, відповідальну за розвиток торговельноекономічних відносин Туреччини та США [20].

Слід зауважити, що документ є ще одним свідченням важливої ролі цієї країни не лише в регіональній, але і в світовій політиці. Турецька Республіка межує з Вірменією, Грузією, Іраком, Іраном, Сирією Грецією та Болгарією, що визначає іiі роль як важливого регіонального гравця. 3 іншого боку, країна є коридором для поставок енергоресурсів в Свропу, що надає їй унікальності у порівнянні з іншими країнами регіону. Не слід забувати, що Туреччина є союзником США і членом НАТО. На фоні зростаючою агресії РФ і конфронтації іiі із Заходом, Турецька 
Республіка є привабливим партнером для багатьох країн та альянсів, зокрема Сполучених Штатів, СС, НАТО тощо.

Важко переоцінити роль Туреччини в американській кампанії в Афганістані, оскільки Туреччина виконувала та виконує низку функцій в межах членства в НАТО. Так вона втретє взяла на себе зобов'язання командувати силами НАТО в Афганістані i, до того ж, відправила туди додатковий контингент [12]. Турецькі військові беруть активну участь у процесі навчання афганської поліції та виконують функції, нетипові для західних країн-членів НАТО, наприклад, беруть участь у створенні необхідних соціальних установ, таких як лікарні чи школи для дівчаток.

За останні кілька років Туреччина посилила свою присутність в Афганській кампанії. Президент Ердоган має на меті зміцнити свої позиції в НАТО та посилити вплив в мусульманському світі. Турецький президент відвідав Афганістан після президентських виборів у 2014 році. Візит Ердогана в Афганістан знаменував початок нових відносин між дома країнами-сусідами. Анкара почала брати активну участь в афганських подіях після 2001 року, коли внаслідок уведення американських військ, режим Талібану зазнав поразки. Виконуючи обов'язки члена НАТО, Туреччина розмістила свої війська в Афганістані в 2002 році [19].

Слід зауважити, що Туреччина - єдина країна-член НАТО, що не зменшила військового контингенту в Афганістані після закінчення воєнної місії в 2014 році. Навпаки, вона посилила свою присутність в сусідній країні, відіграючи провідну роль в тренувальній місії “Рішуча підтримка".

В 2015 році президент Ердоган заявив, що Туреччина могла б посилити довготривалу військову присутність у країні, що межує 3 Китаєм, Іраном, Пакистаном і низкою центрально-азійських країн. Така амбіційна заява свідчить про те, що Туреччина зацікавлена в контролі над Афганістаном і цей контроль почався задовго до місії НАТО. Упродовж тривалого часу турецькі політики не лише відслідковували перебіг подій в сусідній країні, але й налагоджували тісні відносини 3 різними політичними угрупуваннями на території Афганістану. Зважаючи на зацікавлення Туреччини у контролі над Афганістаном, можна припустити, що турецькі політики налагодили контакти з лідерами талібів, що дає їм додаткові важелі впливу на перебіг подій в цій країні. Обидві сторони мають спільні цілі. Однією з таких цілей є спільні намагання тримати під контролем ІДІЛ [19].

Аналізуючи політику Турецької Республіки за останні роки не слід ігнорувати спроби Туреччини стати мусульманським лідером. Намагаючись здійснювати, наскільки це можливо, незалежну політику, Ердоган не приховує амбіцій стати лідером мусульманського світу, позиціонуючи свою країну як альтернативу Ірану та Саудівській Аравії. Упродовж останніх років Анкара неодноразово проводила конференції, присвячені Афганістану. Турецькі політики брали участь як посередники у перемовинах між Афганістаном i Пакистаном у питаннях регіональної безпеки і стабільності. Туреччина закликала Талібан взяти участь у мирних перемовинах з Кабулом. I хоча значного покращення не вдалося досягти, однак такі кроки стали свідченням значного інтересу Анкари у вирішенні долі Афганістану. США та країни НАТО зацікавлені у вирішенні майбутнього Афганістану, проте Анкара намагається використати результати зусиль у власних інтересах, - заявив Фаїз Мохаммед Заланд, професор Кабульського університету 
[19]. Турецький президент намагається переконати США та членів НАТО, що без сприяння Туреччини успіху в Афганістані неможливо досягти. Таким чином Анкара намагається здобути політичні інструменти впливу над західними союзниками.

Цінність Туреччини як члена НАТО зростає з урахуванням того, що це єдина мусульманська країна в НАТО. Завдяки добрим відносинам 3 іранським керівництвом Туреччина може сприяти пошуку шляхів для налагодження американо-іранського діалогу. Інтересам США відповідає готовність Анкари виступати в ролі офіційного або непрямого посередника. Зростання турецькоіранських економічних відносин, взаємовигідних для обох сторін, надає Туреччині особливого статусу, на думку якої Тегеран може зважити.

Сполучені Штати зацікавлені у співпраці з Туреччиною, оскільки затяжна війна в Сирії змусила Вашингтон шукати союзників у вирішенні “сирійської проблеми". Американські політики, як ніколи, розуміють, що напружена ситуація на Близькому Сході потребує активної участі Турецької Республіки у вирішенні близькосхідних проблем, зокрема ситуації в Сирії. I в цьому випадку Туреччина може виступити разом з арабськими країнами для протидії Сирії [7]. Важливо, аби Туреччина не розпочала дії в односторонньому порядку. А до цього країну підштовхують Іран, Сирія та Росія, зацікавлені у посилення хаосу на Близькому Сході. Війна в Сирії перетворила Туреччину на буферну зону між Близьким Сходом та Європою.

Проблемність ситуації полягає в тому, що арабів-мусульман не влаштовує той факт, що Туреччина набирається сил, перетворюється на сильного регіонального лідера і намагається домінувати в регіоні. А підстав для такої позиції - більше ніж достатньо. Ускладнює ситуацію війна в Сирії, сусідній країні, що створює плацдарм для провокацій, на кшталт кривавого теракту 11 травня 2013 року у місті Рейханли та інших містах країни.

Попри небезпеку повномасштабної війни, в яку може вступити Туреччина, на іï боці виступила Саудівська Аравія. 11 лютого 2016 року радник міністра оборони Саудівської Аравії генерал Ахмед Асірі оголосив про те, що Ер-Ріяд планує здійснювати наземні операції в Сирії в березні та квітні 2016 року. День по тому, міністр закордонних справ Королівства Адель аль Джубейр зрозуміло висловився, що настав час для Башара аль-Асада піти 3 посади президента Сирії. I додав, що якщо виникне необхідність, то слід застосувати силу. Подальші події, 13 лютого, свідчать про те, що Ер-Ріяд та Анкара дійшли порозуміння з приводу спільних дій, зокрема щодо використання саудівських військових літаків, що базуються в Інджирліку [15]. Очевидним є той факт, що спільне рішення двох сусідніх із Сирією країн потребує згоди Вашингтону, проте у цій ситуації Америка значною мірою виграє, оскільки союзники ту суперники, що в'язнуть у виснажливій війні, витрачають економічні, військові та людські ресурси, в той час, як Вашингтон може зекономити зусилля, спостерігаючи та контролюючи перебіг подій. По-друге, Америка може не перейматися питанням виникнення нового регіонально лідера, що кине їй виклик найближчим часом.

Відносини між Туреччиною та Сполученими Штатами Америки упродовж каденції Б. Обами залишалися складними і на те були підстави. Політика Туреччини щодо курдів та ІДІЛ ішла врізнобіч із курсом Вашингтону і значної кількості членів НАТО, а наступ Ердогана на демократичні засади і свободу слова 
викликав різку критику у США та Європі [22]. Попри це, Турецька Республіка залишається партнером згаданих країн як член Альянсу. Вона виконує безпекову функцію і це розуміють всі гравці, як регіональні, так і світові. Важлива роль Туреччини як противаги російському впливу в регіоні.

Політика Обами щодо Туреччини, критика політики Ердогана були спрямована на те, щоб змусити президента Турецької Республіки дослухатися американських і європейських політиків, які мають достатньо важелів впливу на Анкару. По-перше, це намагання Анкари долучитися європейської спільноти, поповнивши ряди членів ЄС. По-друге, членство Туреччини в НАТО та Раді Свропи дає Західним країнам ефективні важелі впливу на цю країну.

Незважаючи на співпрацю між Туреччиною та США, членами НАТО, деякі кроки цієї країни викликають у ï партнерів занепокоєння. Нещодавній крок Турецької Республіки, спрямований на купівлю російських зенітних комплексів С400, викликав певні побоювання на Заході, оскільки така політика нагадує загравання Анкари з Москвою. Попри це, у Туреччині заявили, що країна залишається надійним членом НАТО. Про це на прес-конференції сказав прессекретар президента Туреччини Реджепа Таїпа Ердогана Ібрагім Калин, повідомляє Reuters. "За словами речника Ердогана, добрі відносини Туреччини з Росією не $є$ альтернативою зв'язкам країни із Заходом, а швидше є взаємодоповнюючими", йдеться у повідомленні [8 ].

3 січня 2017 року Парламент Туреччини прийняв рішення продовжити військову місію в Афганістані в межах місії НАТО. Парламент уповноважив уряд країни продовжити присутність турецьких військ в Афганістані на два роки під егідою місії НАТО. Такі кроки Туреччини не залишилися поза увагою Сполучених Штатів, які, незважаючи на критику політики Ердогана, досить позитивно оцінюють роль Туреччини у збереженні стабільності та безпеки регіону.

В травні 2017 року Р. Ердоган здійснив візит до Вашингтону, де він зустрівся 3 чинним президентом США Д. Трампом [16]. Президент США високо оцінив зусилля Туреччини у питанні стабілізації ситуації в боротьбі проти ІДІЛУ та в Сирії. Незважаючи на теплий прийом, двосторонні відносини залишаються напруженими через відмову Вашингтону видати турецького клерика, якого Ердоган звинувачує у липневій спробі державного перевороту.

Напруження додає той факт, що Трамп прийняв рішення поставити зброю курдським бойовикам, що воюють проти ІДІЛ біля міста Ракка. Туреччина відносить цих бойовиків до прихильників РПК (Робітничої партії Курдистану).

Виступаючи у Вашингтоні, президент Туреччини зауважив, що Туреччина не візьме до уваги плани курдів стати частиною майбутнього Туреччини. “Терористичній організації немає місця в майбутньому регіону”, - зауважив політик [16]. Ердоган здійснив візит з конкретною метою - започаткувати нову еру в американо-турецьких відносинах, об'єднавши зусилля у боротьбі 3 тероризмом $\mathrm{i}$ розширюючи економічні та торгові відносини між країнами. Турецький політик не оминув шансу висловити занепокоєння 3 приводу відмови видати клерика турецького походження Фетули Гулена.

Візит Ердогана до Вашингтону був зумовлений іще однією причиною. Турецький лідер намагався переконати президента США відмовитися від рішення озброїти курдських бойовиків і інформувати Трампа про мирний план щодо Сирії, 
який Анкара узгодила з Росією та Іраном. План передбачав створення чотирьох зон зменшення вогню в Сирії.

Зустріч президентів доповнила зустріч Секретаря оборони США Дж. Метітса та Міністра оборони Туреччини Фікра Ісіка. Високопосадовці обговорили низку питань безпеки, ключовим з яких стало питання кризи в Сирії.

Підсумовуючи викладений матеріалі, хотілося б зробити деякі висновки щодо розвитку американо-турецьких відносин за останні роки:

- незважаючи на підйоми та спади у відносинах, США традиційно розглядає Туреччину як вагомий важіль політичного впливу в регіоні.

- $\quad$ внутрішня політика президента Ердогана ускладнює відносини Туреччини з Вашингтоном, що створює додаткові труднощі для реалізації спільних інтересів.

- США переслідують власні інтереси у відносинах 3 Турецькою Республікою.

- Туреччина, незважаючи на членство в НАТО, намагається здійснювати незалежну зовнішню політику, що загострює відносини з Західними країнами.

Перспективу подальших розвідок вбачаємо у вивченні та аналізі турецькоіранських та турецько-російських відносин, які впливають на перебіг подій в регіоні, його стабільність та безпеку.

\section{Література}

1. Погорська I.I. Міжнародно-політична дія американського глобалізму: автореф. дис. на здобуття наук. ступеня докт. політ. наук: спец. 23.00.04 “Політичні проблеми міжнародних систем та глобального розвитку" / І.Погорська. - Київ, 2010. - 32 с.

2. Головань О.О. Еволюція зовнішньої політики США на початку XXI століття: автореф. дис. на здобуття наук. ступеня канд. політ. наук: спец. 23.00.04 “Політичні проблеми міжнародних систем та глобального розвитку" / О.Головань. - Миколаїв, 2016. - 22 с.

3. Кияниця Л.Л. Вплив “Арабської весни ” на співвідношення сил на Близькому Сході: автореф. дис. на здобуття наук. ступеня канд. політ. наук: спец. 23.00 .04 "Політичні проблеми міжнародних систем та глобального розвитку" / Л.Кияниця. - Київ, 2015. - 20 с.

4. Ратніков М.І. Проблеми американо-турецьких відносин за минуле десятиліття / М.Ратніков // Актуальні проблеми міжнародних відносин. - Вип. 103 (Частина 1). - 2011. - С. 18-23.

5. Московець В.С.Курдське питання в Американсько-турецьких відносинах / В.Мостовець // "Історія" Наукові праці. - Вип.134. Том 137. 2011. - С. 137-140.

6. Чубрикова О. Туреччина в ООН у 2003-2015 роках: шлях-утвердження держави-лідера // "UA Foreign Affairs". 13.01.2016. [Електронний ресурс] - Режим доступу: http://uaforeignaffairs.com/ua/ekspertna-dumka/view/article/turechchina-v-oon-u-2003-2015rokakh-shljakh-utverdzhennja-derzhav (дата звернення: 2 травня 2017 р.) - Назва з екрану.

7. Каспрук В. Сирійське покарання Туреччини // Дзеркало Тижня. - 17 травня 2013. [Електронний ресурс] - Режим доступу: https://dt.ua/international/siriyske-pokarannyaturechchini-_.html (дата звернення: 2 травня 2017 p.) - Назва з екрану.

8. Глухов Д. Турция купила у России ЗРК С-400 // Комсомольская Правда в Украине. 25.07.2017. [Електронний ресурс] - Режим доступу: https://kp.ua/politics/581884-turtsyia-kupyla-u-rossyyzrk-s-400 (дата звернення: 2 травня 2017 р.) - Назва з екрану.

9. Свистунова И.А. Турция и США обсуждают перспективы сотрудничества // [Електронний pecypc] - Режим доступу: http://www.iimes.ru/rus/stat/2009/20-04-09a.htm (дата звернення: 2 травня 2017 р.) - Назва з екрану. 
10. Свистунова И.А. Об отношениях Турции и США. // Раздел «Публикации». [Електронний pecypc] - Режим доступу: http://www.iimes.ru/rus/stat/2009/20-12-09.htm (дата звернення: 2 травня 2017 р.) - Назва з екрану.

11. Калугин П.Е. Современное стратегическое сотрудничество Российской Федерации с Турцией в сфере энергетики: автореф. дис. на соиск науч. степени канд. истор. наук: спец. 07.00.03 "Всеобщая история" / П.Калугин. - Иркутск, 2014. - 22 с.

12. Гурьев А.А. Оценка Турцией действий США в Ираке. // Раздел «Публикации». [Электронный pecypc] - Режим доступа: http://www.iimes.ru/rus/stat/2005/27-05-05.htm (дата обращения: 2 мая 2017 г.) - Название с экрана.

13. Стародубцев И.И. К вопросу о современном состоянии американо-турецких отношений и их перспектив. // Раздел «Публикации». [Электронный ресурс] - Режим доступа: http://www.iimes.ru/rus/stat/2009/24-04-09.htm (дата обращения: 2 мая 2017 г.) - Название с экрана.

14. Накисбаєв Д.В. Американо-турецкие отношения в эпоху глобализации и перспективы их развития: автореф. дис. на соиск науч. степени канд. полит. наук: спец. 23.00.04 “Политические проблемы международных отношений и глобального развития" /Д.Накисбаев. - Москва, 2008. - 22 с.

15. Санторо Д. Почему Эрдоган хочет вторгнуться в Сирию // ИНОСМИРУ. 23.02.2016. [Электронный pecypc] - Режим доступа: http://inosmi.ru/reg_mideast/20160223/235504604.html (дата обращения: 2 мая 2017 г.) - Название с экрана.

16. Gaouette N. Trump welcomes Erdogan amid US-Turkey strains // CNN. May16, 2017. [Electronic Resource] - Mode of Access: http://edition.cnn.com/2017/05/16/politics/trump-erdoganvisit/index.html (Last Access: May 23, 2017). - Title from the Screen.

17. Momani B. «IMF Surveillance and America s Turkish Delight» // Perspectives. - 2006. - Vol. 14, No. 2. - p. 12. - [Electronic Resource] - Mode of Access: http://www.iir.cz/display.asp?ida=368 (Last Access: May 23, 2017). - Title from the Screen.

18. Momani B. «IMF Surveillance and America s Turkish Delight.» // Perspectives. - 2006. - Vol. 14, No. 2. - p. 5-25. - [Electronic Resource] - Mode of Access: http://www.iir.cz/display.asp?ida=368 (Last Access: May 23, 2017). - Title from the Screen.

19. Masood Saifullah. Is Turkey's Erdogan seeking a leading role in Afghanistan / DW. 06.07.2017. [Electronic Resource] - Mode of Access: http://www.dw.com/en/is-turkeys-erdogan-seeking-aleading-role-in-afghanistan/a-39575830 (Last Access: August 31, 2017). - Title from the Screen.

20. Ozel S., Yilmaz S., Akyuz A. Rebuilding a Partnership: Turkish-American Relations for a New Era A Turkish Perspective. // TUSIAD Publication No-T/2009-04/490. [Electronic Resource] - Mode of Access: http://www.tusiad.us/specific_page.cfm?CONTENT_ID=856\# (Last Access: August 31, 2017). - Title from the Screen.

21. Nkambeh F. Turkey extends its NATO mission in Afghanistan // Anadolu Agency. 03.01.2017. [Electronic Resource] - Mode of Access: http://aa.com.tr/en/todays-headlines/turkey-extends-itsnato-mission-in-afghanistan/719741 (Last Access: August 31, 2017). - Title from the Screen.

22. Членство Туреччини в НАTO сьогодні проблемна необхідність // 112 UA. 31 березня 2016. [Електронний ресурс] - Режим доступу: https://ua.112.ua/mnenie/chlenstvo-turechchyny-v-natosohodni--problemna-neobkhidnist-301881.html (дата звернення: 30 травня 2017 р.) - Назва 3 екрану.

\section{References}

1. POHORS"KA, I. (2010) Mizhnarodno-politychna diya amerykans"koho hlobalizmu. Unpublished Thesis $(\mathrm{PhD})$, Instytut svitivoi ekonomiky ta mizhnarodnyh vidnosyn NANU.

2. HOLOVAN", O. (2016) Evolyuciya zovnishn"oyi polityky SShA na pochatku XXI stolittya. Unpublished Thesis ( $\mathrm{PhD}$ ), Chornomors'kyi Derzhavniy Universytet imeny petra Mogyly.

3. KYYANYCYA, L. (2015) Vplyv "Arabs"koyi vesny " na spivvidnoshennya syl na Blyz"komu Sxodi. Unpublished Thesis (PhD), Natsional'niy Universytet Kievo-Mogylans'ka Akademiya. 
4. RATNIKOV, M. (2011) Problemy amerykano-turec"kyx vidnosyn za mynule desyatylittya. Aktual"ni problemy mizhnarodnyx vidnosyn. Vyp. 103 (1). P. 18-23.

5. MOSKOVEC", V. (2011) Kurds"ke pytannya v Amerykans"ko-turec"kyx vidnosynax. Istoriya" Naukovi praci. Vyp.134 (Tom 137). P. 137-140.

6. CHUBRYKOVA, O. (2016) Turechchyna v OON u 2003-2015 rokax: shlyax-utverdzhennya derzhavy-lidera. UA Foreign Affairs. - [Online] Available from: http://uaforeignaffairs.com/ua/ekspertna-dumka/view/article/turechchina-v-oon-u-2003-2015rokakh-shljakh-utverdzhennja-derzhav (Accessed 19.09.2017).

7. KASPRUK, V. (2013) Syrijs"ke pokarannya Turechchyny. Dzerkalo Tyzhnya. [Online]. - Available from: https://dt.ua/international/siriyske-pokarannya-turechchini-_.html (Accessed 19.09.2017).

8. HLUXOV, D. (2017) Turcyya kupyla u Rossyy ZRK S-400. Komsomol"skaya Pravda v Ukrayne. [Online]. Available from: https://kp.ua/politics/581884-turtsyia-kupyla-u-rossyy-zrk-s-400 (Accessed 19.09.2017).

9. SVYSTUNOVA, Y. (2009) Turcyya y SShA obsuzhdayut perspektyvy sotrudnychestva. [Online] Available from: http://www.iimes.ru/rus/stat/2009/20-04-09a.htm (Accessed 19.09.2017).

10. SVYSTUNOVA, Y. (2009) Ob otnoshenyyax Turcyy y SShA. «Publykacyy». [Online] Available from: http://www.iimes.ru/rus/stat/2009/20-12-09.htm (Accessed 19.09.2017).

11. KALUHYN, P. (2014) Sovremennoe stratehycheskoe sotrudnychestvo Rossyjskoj Federacyy s Turcyej $v$ sfere эnerhetyky. Unpublished Thesis (PhD), Yrkutskiy Gosudarstvenniy universitet.

12. HUR"EV A. (2005) Ocenka Turcyej dejstvyj SShA v Yrake. «Publykacyy». [Online] Available from: http://www.iimes.ru/rus/stat/2005/27-05-05.htm (Accessed 19.09.2017).

13. STARODUBCEV, Y. (2009) K voprosu o sovremennom sostoyanyy amerykano-tureckyx otnoshenyj y yx perspektyv. «Publykacyy». [Online] Available from: http://www.iimes.ru/rus/stat/2009/24-0409.htm (Accessed 19.09.2017).

14. NAKYSBAYEV, D. (2008) Amerykano-tureckye otnoshenyya $v$ эрохи hlobalyzacyy y perspektyvbl yx razvytyya. Unpublished Thesis (PhD), Diplomaticheskaya Akademia MID Rossii.

15. SANTORO, D. (2016) Pochemu Эrdohan xochet vtorhnut"sya v Syryyu. YNOSMYRU. [Online] Available from: http://inosmi.ru/reg_mideast/20160223/235504604.html (Accessed 19.09.2017).

16. GAOUETTE, N. (2017) Trump welcomes Erdogan amid US-Turkey strains. CNN. [Online]. May 16. Available from: http://edition.cnn.com/2017/05/16/politics/trump-erdogan-visit/index.html (Accessed 19.09.2017).

17. MOMANI, B. (2006) IMF Surveillance and America s Turkish Delight. Perspectives. [Online]. Vol. 14 (2). p. 12. - Available from: http://www.iir.cz/display.asp?ida=368 (Accessed 19.09.2017).

18. MOMANI, B. (2006) IMF Surveillance and America s Turkish Delight. Perspectives. [Online]. Vol. 14 (2). p. 5-25. - Available from: http://www.iir.cz/display.asp?ida=368 (Accessed 19.09.2017).

19. MASOOD, S. (2017) Is Turkey's Erdogan seeking a leading role in Afghanistan. DW. [Online]. Available from: http://www.dw.com/en/is-turkeys-erdogan-seeking-a-leading-role-in-afghanistan/a39575830 (Accessed 19.09.2017).

20. OZEL, S., YILMAZ, S. and AKYUZ, A. (2009) Rebuilding a Partnership: Turkish-American Relations for a New Era - A Turkish Perspective. TUSIAD Publication No-T/2009-04/490. [Online] - Available from:: http://www.tusiad.us/specific_page.cfm?CONTENT_ID=856\# (Accessed 19.09.2017).

21. FELIX, TIH NKAMBETH. (2017) Turkey extends its NATO mission in Afghanistan. Anadolu Agency. [Online]. - Available from: http://aa.com.tr/en/todays-headlines/turkey-extends-its-natomission-in-afghanistan/719741 (Accessed 19.09.2017).

22. Chlenstvo Turechchyny v NATO s"ohodni problemna neobxidnist" // 112 UA. 31 bereznya 2016. [Online] - Available from: https://ua.112.ua/mnenie/chlenstvo-turechchyny-v-nato-sohodni-problemna-neobkhidnist-301881.html (Accessed 19.09.2017). 
Anatoliy Khudoliy, Ph.D. in Political Science, Professor, Ostroh academy National University, Ostroh, Ukraine

\section{AMERICAN-TURKISH RELATIONSHIPS AT THE BEGINNING OF THE XXI CENTURY}

Abstract. The article deals with American-Turkish relationships during 2000-2017.

Analyzing the period of seventeen years of cooperation between two countries we distinguished stages of relationships and followed how they changed within time.

The author focused on several important aspects related to foreign policy course of both countries. Among them: political, military and economic cooperation between Washington and Ankara for the period mentioned above.

Main tendencies of American-Turkish relationships in the context of multifaceted cooperation are illustrated. The author attempted to analyze development of relationships during terms of three American Presidents, such as G.W. Bush, B. Obama and D. Trump. Every period of two-side relationships had its advantages and disadvantages, shaped by various factors.

The foreign policy of Turkey is oriented to stabilization of the situation in the region. Along with it, Turkey performs security functions in the region whether it deals with Afghanistan or Syria.

The author tried to identify American priorities in the context considering its own pragmatic purposes and national interests in relationships with Turkey. Two-side relations in the light of Syrian was and war in Afghanistan are analyzed. We have identified and described important factors that reduce strategic partnership. They weaken relationships between two countries.

The USA was quite decisive at the very beginning of the XXI century when it needed Turkey in order to accumulate efforts before the invasion of Iraq and later on when Washington started war in Afghanistan. The Turkish Republic supported the USA in its strategy first in Iraq and then in Afghanistan and over the last years in Syria.

Military cooperation developed quite effectively for a long period. Washington also provided financial, economic and military support of turkey, but demanded development of democracy in the country.

Turkey as a member of NATO did and does a lot in order provide security and accomplish missions due to its responsibilities. We identified and analyzed definite steps made by Turkey and the USA for the sake of the regional security.

Apart from military and security spheres, both countries develop business and economic relationships. Since 2000, Turkey has become an important market for American production.

Along with positive, there are negative spots in the relationships. Despite numerous requests made by Turkish Government, American administrations support Kurds with weapons and such steps undermine trust between the countries.

America is dependent on Turkey in solving the Middle East crisis. The war in Syria is raging and it requires efforts from both sides despite misunderstanding and lack of trust.

Key words: the USA, Turkey, American-Turkish relationships, Syria, Afghanistan, NATO, national interests of the USA. 